DOI: http://doi.org/10.18290/rkult21123-2

\author{
JUSTYNA SZULICH-KAŁUŻA
}

\title{
METAFORY WIZUALNE PANDEMII COVID-19 W MEMACH INTERNETOWYCH
}

\section{WPROWADZENIE}

Globalna pandemia COVID-19 stała się wyzwaniem dla współczesnych społeczeństw na wielu obszarach. Autorzy raportu Życie codzienne w czasach pandemii nazywają ją okresem reorganizacji codzienności, obejmującym — po pierwsze - przeobrażenia więzi (zwiększenie lub zmniejszenie samotności, oddalenie lub zbliżenie do innych, niedosyt lub nadmiar kontaktów), po drugie — przeobrażenia temporalnej organizacji codzienności, wreszcie po trzecie - nadmiar informacji i kontaktu z mediami, które wymuszają konieczność selektywnego traktowania info- i media-sfery ${ }^{1}$. Wraz ze zmianą form społecznego funkcjonowania należy dostrzec modyfikacje praktyk komunikacyjnych, uzależnionych w niespotykanej wcześniej skali od Internetu i mediów społecznościowych. Wśród wielu form komunikacyjnych należy wymienić memy internetowe, swoisty fenomen komunikacyjny i medium ekspresywnej aktywności w nowych mediach. Naukowym analizom memy są poddawane najczęściej w zakresie różnorodności form i treści, sposobów ich tworzenia i kanałów rozprzestrzeniania ${ }^{2}$. W okresie

Dr hab. JustYNA SzULICH-KaŁUŻA, prof. KUL - Katolicki Uniwersytet Lubelski Jana Pawła II, Wydział Nauk Społecznych, Instytut Dziennikarstwa i Zarządzania (dyrektor), Katedra Komunikacji Wizualnej i Nowych Mediów; adres do korespondencji: Al. Racławickie 14, $20-950$ Lublin, e-mail: justyna.szulich-kaluza@ kul.pl; ORCID: https://orcid.org/0000-0002-6845-168X.

${ }^{1}$ Rafał DrozDowski i in., Życie codzienne $w$ czasach pandemii. Raport z pierwszego etapu badań (Poznań: Wydział Socjologii UAM, 2020), 23-24. Uniwersytet Adama Mickiewicza w Poznaniu. Wydział Socjologii, dostęp 24.05.2021, http://socjologia.amu.edu.pl/aktualnosci/socjologia/ 464-zycie-codzienne- w-czasach-pandemii-raport.

${ }^{2}$ Warto wskazać na pewien interesujący artykuł, w którym autorka wykazała, że tworzone podczas pandemii memy odnosiły się do sfer życia bliskich internautom: przede wszystkim do ich życia codziennego oraz powszechnie dostępnego przekazu medialnego (stąd takie tematy, jak polityka, sytuacja globalna). Zuzanna JezIERSKA, „Poznawcze i emocjonalne charakterystyki 
pandemii stały się kreatywnym sposobem na komunikowanie koronawirusowych doświadczeń użytkowników, przede wszystkim humorystycznych reakcji na bieżące wydarzenia związane m.in. z sytuacją pandemiczną, działalnością władz, służb medycznych i mundurowych w zakresie wprowadzania i przestrzegania reżimu sanitarnego. Okazały się popularnym środkiem współtworzącym konstrukt medialny pandemii.

Przedmiotem artykułu jest charakterystyka metafor wizualnych o pandemii w memach polskich internautów, które pojawiły się w sieci od momentu ogłoszenia w Polsce stanu pandemicznego. Materiał do analiz metafor wyselekcjonowano, kierując się dwoma kryteriami: po pierwsze, szukano memów o najbogatszej semantyce wizualnej i, po drugie, wybrano memy spełniające przynajmniej jedną $\mathrm{z}$ definicyjnych cech metafory wizualnej. W przypadku drugiego kryterium posłużono się czterema wskaźnikami definicyjnymi metafory wizualnej. Zgodnie z nimi wystarczyło, że wizualizacja spełniała jedną z następujących właściwości: (1) mamy do czynienia z przypadkami, w których występuje wizualna fuzja elementów z dwóch odmiennych obszarów znaczeniowych lub gatunkowych w jedną przestrzennie ograniczoną całość; (2) pojawia się mechanizm zastąpienia oczywistego i oczekiwanego elementu nieoczekiwanym, burzącym proste, logiczne skojarzenie; (3) zawartość jest kompozycją znaków słownych i obrazowych, które poprzez swój szczególny stosunek do siebie tworzą pospołu nową jakość; (4) wizualne przedstawienie jest użyte jako okazja do myślenia metaforycznego. Memy archiwizowano w okresie od 17 maja 2021 r. do 25 maja 2021 r. z trzech witryn internetowych: Dziennik Polski, https://dziennikpolski24.pl, GK24.pl [Głos Koszaliński], https://gk24.pl/, Polska Times, https://polska times.pl/. Jak widać, są to witryny trzech tytułów prasy codziennej. Wymienione dzienniki posiadały specjalną zakładkę zatytułowaną „Najlepsze memy o koronawirusie/kwarantannie z internetu". Wyselekcjonowane memy można podzielić na trzy zasadnicze grupy: memy o koronawirusie, memy o codziennych praktykach w sytuacji reżimu sanitarnego (kwarantanny) oraz memy o działaniach służb mundurowych i medycznych. Dalej w tekście każda z wymienionych grup ma swoje reprezentacje w przykładach. Zamierzeniem badawczym było przeprowadzenie analizy opisowej metafor wizualnych na przykładzie wybranych memów internetowych. Postępowanie badawcze w podjętym projekcie obejmowało kilka etapów: (1) wybór i selekcja memów do analizy zawartości; (2) wstępna kategoryzacja memów - wybór memów o bogatym 
znaczeniu metaforycznym; (3) przygotowanie klucza analitycznego według trzech punktów: wskazanie domeny docelowej, domeny źródłowej i mapowania cech z domeny źródłowej do domeny docelowej; (4) przeprowadzenie opisowej analizy metafor.

Struktura artykułu jest następująca. W pierwszej części omówiono zagadnienia teoretyczne dotyczące memów i metafor wizualnych, które są istotne dla dalszych analiz autorskich. Druga część jest poświęcona metodologii i analizom szczegółowym wybranych przykładów metafor wizualnych pandemii. Ostatnia część zawiera kilka uwag końcowych o charakterze podsumowującym.

\section{MEMY INTERNETOWE - W KONTEKŚCIE METAFORYCZNYCH ZNACZEŃ}

Słowo mem (ang. meme) jest skrótem angielskiego mimeme, będącego transpozycją greckiego $\mu$ í $\eta_{\mu \alpha}($ mimēma $)$ - naśladownictwo, kopia, podróbka, nawiązującego do $\mu$ í $\eta \sigma_{1 \varsigma}$ (mimēsis) - naśladowanie, imitowanie ${ }^{3}$. Do prekursorów, a następnie propagatorów memetyki, dziedziny nauki badającej, zarówno teoretycznie jak i empirycznie, procesy replikacji, rozprzestrzenianie się i ewolucję memów jako elementów kultury, które są przekazywane w sposób analogiczny do biologicznego przekazywania genów (w tym memów w postaci obrazu, wideo, frazy itp., rozpowszechnianych za pośrednictwem Internetu i często zmienianych w sposób kreatywny lub humorystyczny), należą Richard Dawkins, Henry Plotkin, Daniel C. Dennett, Richard Brodie, Maynard Smith oraz Susan Blackmore ${ }^{4}$.

Dla użytkowników w potocznym ujęciu memy są to obrazy komentowane i rekomentowane w celach humorystycznych, satyrycznych i politycznych, rzadziej tworzone z myślą o estetyce przekazu i pokazaniu jakiegoś piękna, wysublimowanego dowcipu czy patosu. Zgrabną słownikową definicją jest przyrównanie memu do tekstu kultury, w którym są wykorzystane znaki

\footnotetext{
${ }^{3}$ Co ciekawe, podobnie brzmiący termin, oznaczający ewolucję kulturową, pojawił się już w 1870 r., kiedy austriacki socjolog Ewald Hering ukuł frazeologizm „die Mneme” (tym razem od greckiego $\mu \nu \eta ́ \mu \eta$ [mnēmē] oznaczającego pamięć), którego niemiecki biolog Richard Semon użył w tytule książki Die Mnemischen Empfindungen in ihren Beziehungen zu den Originalempfindungen [Wrażenia mnemiczne w ich związku z pierwotnymi doznaniami]. David HulL, „Taking Memetics Seriously: Memetics Will Be What We Make It”, w: Darwinizing Culture: The Status of Memetics as a Science, red. Robert Aunger (Oxford: Oxford University Press, 2000), 43-168.

${ }^{4}$ Ignacy S. FIUT, „Filozoficzne konsekwencje memetyki”, dostęp 25.05.2021, http://www.racjo nalista.pl/kk.php/t,4712.
} 
językowe i wizualne pozyskiwane z zasobów kultury popularnej, np. fragmenty filmów, seriale telewizyjne, programy rozrywkowe, reprodukcje obrazów5 ${ }^{5}$ Tożsamość twórców jest zazwyczaj ukryta - są one tworzone i powielane anonimowo. Uznajemy je za formę kreatywnych aktywności, które wiele mówią o autorach i praktykach memowych oraz zachęcają do myślenia na nowe sposoby. Mem internetowy wyróżnia zatem to, że jest zdigitalizowaną jednostką informacji (np. w postaci obrazu, filmu, dźwięku), która replikuje się wyłącznie drogą internetową, skopiowaną, przetworzoną i w tej przetworzonej formie opublikowaną $w$ Internecie ${ }^{6}$. W sieci memy są wytwarzane i przesyłane w celu propagowania różnorodnych treści w formie żartów, plotek, pogłosek i filmików. Rozpowszechniane w oryginalnej lub pochodnej postaci są nazywane spin-offami wersji pierwotnej ${ }^{7}$. Obraz, tekst i praktycznie każdy szablon strukturalny mema podlega ciągłemu łączeniu, przekształcaniu i tworzeniu nowych memów, czyli spin-offów swoich poprzednich wersji ${ }^{8}$. Struktura mema nie jest czymś stałym i zakładanym, jego ciągłe przekształcanie oznacza permanentne odnawianie znaczeń i uznanie, że mem jest dobry. Użytkownicy korzystają z ram, które, z jednej strony, odnoszą do osoby postrzegającej dany mem, z drugiej zaś do procesu, w którym użytkownicy rozwijają szczególną konceptualizację problemu, łącznie z projektowaniem reorientacji ich myślenia o danym zagadnieniu czy wydarzeniu. Ramy (szablony) na ogół implikują spójne układy metafor splecione w narracyjne zbiorowe formy. W opracowaniu podjęto próbę odszukania i odczytania znaczeń metaforycznych ukrytych w metaforach wizualnych.

\section{METAFORY WIZUALNE — RODZAJE I TERMINOLOGIA BADAWCZA}

W ostatnich latach rośnie liczba publikacji opartych na empirycznych badaniach nad naturą oraz specyfiką metafor wizualnych. Szczegółowo opra-

\footnotetext{
${ }^{5}$ Jakub NowAK, „Memy internetowe. teksty (cyfrowej) kultury językiem krytyki społecznej”, w: Współczesne media. Język mediów, red. Iwona Hofman, Danuta Kępa-Figura (Lublin: Wydawnictwo Uniwersytetu Marii Curie-Skłodowskiej, 2013), 231.

${ }^{6}$ Adam Walkiewicz, „Czym są memy internetowe? Rozważania z perspektywy memetycznej”, Teksty z Ulicy. Zeszyt Memetyczny nr 12(2012): 50.

${ }^{7}$ Limor Shifman, „Memes in a Digital World. Reconciling with a Conceptual Troublemaker”, Journal of Computer-Mediated Communication, nr 18 (2013): 362.

${ }^{8}$ Charalambos Konstantineas, Georg Vlachos, „Internet Memes. Humour in Late Modernity and Encroachment Upon the Mainstream”, dostęp 20.04.2021, http://www.inter-disciplinary.net/ critical-issues/wpcontent/uploads/2012/06/vlachosvispaper.pdf.
} 
cowane zostały metafory wizualne $\mathrm{w}$ różnych gatunkach, takich jak rekla$\mathrm{ma}^{9}$, film $^{10}$, kreskówki ${ }^{11}$, komiksy, mangi i animacje ${ }^{12}$.

Metafora jest jednym z podstawowych i uniwersalnych mechanizmów komunikacyjnych. Najstarszą definicję metafory sformułował Arystoteles, który rozumiał ją jako przeniesienie nazwy z gatunku na rodzaj bądź z rodzaju na gatunek, jak również przeniesienie nazwy z jakiejś rzeczy na inną rzecz przy użyciu analogii. Analogię z kolei tłumaczył matematycznie jako rodzaj odniesień proporcjonalnych, charakteryzujących podobieństwa przedmiotów na podstawie równoległości występujących między nimi wspólnych $\operatorname{cech}^{13}$. W przyjętej perspektywie badawczej metafora, podobnie jak rama, jest narzędziem poznawczym, dzięki któremu podmiot postrzegający może nazwać i objaśnić zdarzenie zaistniałe w rzeczywistości ${ }^{14}$. Zakładam, że metafora pojęciowa nie ogranicza się wyłącznie do sfery języka werbalnego i uznaję jej właściwość polegającą na przejawianiu się poprzez inne sposoby komunikacji, takie jak np. obrazy, rysunki, dźwięk, muzyka, gesty czy język

${ }^{9}$ Barbara J. PhILlips, „Understanding visual metaphor in advertising”, w: Presuasive Imagery. A Consumer Response Pespective, red. Linda M. Scott i Rajeev Batra (Mahwah,NJ/London: Lawrence Erlbaum, 2003), 297-310; Amy A. Wiggin i Christine M. Miller, „Uncle Sam Wants You! Exploring Verbal-Visual Juxtapositions in Television Advertising”, w: Presuasive Imagery. A Consumer Response Pespective, red. Linda M. Scott and Rajeev Batra (Mahwah,NJ/London: Lawrence Erlbaum, 2003), 267-295; Eija Ventola, Charles Cassiliy i Martin Kaltenbacher, Perspectives on Multimodality (Amsterdam: Benjamins, 2004); Marisol Velasco i Pedro FuerTES, „Towards a critical cognitive-pragmatic approach to gender metaphors in Advertising English", Journal of Pragmatics, nr 38(11) (2006): 1982-2002; Marisol Velasco i Pedro Fuertes, „Olfactory and olfactory-mixed metaphors in print ads of perfumes”, Annual Review of Cognitive Linguistics, $\mathrm{nr} 4$ (2006): 217-252; Veronica KolleR, „Brand images: Multimodal metaphor in corporate branding messages", w: Multimodal metaphor, red. Charles Forceville, Eduardo Urios-Aparisi (Berlin/New York: Mouton de Gruyter, 2009), 45-71.

${ }^{10}$ Noel Carroll, „Visual metaphor”, w Aspects of Metaphor, red. Jaakko Hintikka (Dordrecht: Kluwer, 1994), 189-223; Noel CARroll, „A note on film metaphor”, w Theorizing the Movie Image, red. Noel Carroll (Cambridge: Cambridge University Press, 1996), 212-223.

${ }^{11}$ John M. Kennedy, „Metaphor in Pictures”, Perception, nr 11(5) (1982): 589-605.

${ }^{12}$ Charles ForCeville, „Metaphors in pictures and multimodal representations”, w The Cambridge Handbook of Metaphor and Thought, red. Raymond W. Jr. Gibbs (Cambridge: Cambridge University Press, 2008), 462-482; Bart EERDEN, „Anger in Asterix: The metaphorical representation of anger in comics and animate films", w Multimodal metaphor, red. Charles Forceville i Eduardo Urios-Aparisi (Berlin/New York: Mouton de Gruyter, 2009, 243-264; Kazuko SHINOHARA i Yoshihiro MATSUnAKA, „Pictorial metaphors of emotion in Japanese comics”, w Multimodal metaphor, red. Charles Forceville i Eduardo Urios-Aparisi (Berlin/New York: Mouton de Gruyter, 2009), 265-296.

${ }^{13}$ Mieczysław A. KRĄPIEC, „Analogia”, w Wprowadzenie do filozofii (Lublin: Redakcja Wydawnictw KUL, 1992), 131.

${ }^{14}$ Agnieszka LiBURA, Wyobraźnia $w$ języku. Leksykalne korelaty schematów wyobrażeniowych (Wrocław: Centrum — Peryferie — Siły, 2000), 46. 
ciała. I jeśli najprościej określić metaforę jako charakterystyczny dla języków naturalnych sposób kodowania informacji o świecie, to analogicznie można zdefiniować metaforę wizualną jako kodowanie informacji o otaczającej rzeczywistości za pomocą języka obrazu. Metafora wizualna (lub obrazowa) jest najczęściej badanym niewerbalnym sposobem ujęć metaforycznych. Obrazy mają percepcyjną bezpośredniość, której brakuje w języku. Każde wizualne przedstawienie może być postrzegane jako przykład metafory wizualnej pod warunkiem, że jej użycie jest okazją do myślenia metaforycznego ${ }^{15}$. Na potrzeby analiz własnych chciałabym wskazać na kilka stwierdzeń o metaforach wizualnych jako interesującym instrumentarium badawczym, na które zwrócił uwagę holenderski semiotyk i medioznawca Charles Forceville: (1) metafory niewerbalne różnią się od metafor werbalnych, mają bowiem bardziej zmysłowy i emocjonalny wpływ na widzów; (2) metafory wizualne osiągają większą apelację międzynarodową, ponieważ nie polegają wyłącznie na kodach językowych; (3) metafory wizualne pozwalają na subtelniejsze sposoby przekazywania i osiągania ich retorycznych efektów w bardziej dyskretny sposób ${ }^{16}$. Co szczególnie istotne, natura metafor wizualnych pozwala także na wskazanie interesujących praktyk badawczych: (1) mnogość odczytów i interpretacji; (2) możliwość wspólnego negocjowania znaczeń wizualnych przez twórców i odbiorców; (3) praktyka rozróżnienia między dosłownym i metaforycznym myśleniem (dwa poziomy odczytu na wzór denotacji i konotacji); (4) możliwość ustalenia wspólnych metaforycznych wzorców myślowych, znaków, symboli które pełnią funkcje metafor; (5) możliwość ustalenia wysoce konwencjonalnych (umownych) wyrażeń słownych wzmacnianych przez reprezentacje wizualne. W opracowaniu przyjęto także założenia koncepcji metafory multimodalnej, Ch. Forceville'a. W definicji opisał jej swoistą cechę — domeny docelowe, źródłowe są odwzorowywane, reprezentowane lub sugerowane przez co najmniej dwa różne systemy znaków, z których jeden może być np. językiem, drugi oprawą wizualną ${ }^{17}$. To, jak dokładnie interpretacja metafor obrazowych i multimodalnych różni się od ich werbalnych odpowiedników, jest wciąż w dużej mierze obszarem niezbadanym, towarzyszące im czynniki strukturalne wydają się pełnić funkcje łatwiej identyfikowalne. Po pierwsze, multimodalna

${ }^{15}$ John M. Kennedy, Christopher D. Green i John Vervaeke, ,Metaphoric Thought and Devices in Pictures", Metaphor and Symbolic Activity, nr 8(3) (1993): 244.

${ }^{16}$ Charles Forceville, „Metaphor in pictures and multimodal representations, w The Cambridge Handbook of Metaphor and Thought, red. Raymond W. Jr. Gibbs (Cambridge: Cambridge University Press, 2008), 462-482.

${ }^{17}$ Ibid., 465. 
natura celu i źródła oznacza, że są one odbierane inaczej niż ich słowne odpowiedniki: obrazy, dźwięki i gesty mają percepcyjną bezpośredniość, której brakuje w języku. W przeciwieństwie do metafor monomodalnych (np. prototypowa metafora językowa) metafory multimodalne są reprezentowane w różnych trybach. Badania nad wizualnymi kanałami metafor multimodalnych prowadzą przede wszystkim badacze języka filmu. Trevor Whittock w opracowaniu Metaphor and film („Metafora i film”) ${ }^{18}$ pokazuje, że filmy fabularne są przesiąknięte metaforami świadomie wprowadzonymi przez reżyserów. Badanie metafory filmowej zmusza do ponownego przemyślenia natury samej metafory oraz sposobów rozpoznawania i rozumienia filmowych obrazów, a także ich interpretacji. Autor identyfikuje podstawowe formy metafory filmowej, a także dostarcza analizy operacji umysłowych, które trzeba do niej wprowadzić. Najnowsze osiągnięcia w psychologii poznawczej, zwłaszcza odnoszące się do natury i formowania się kategorii poznawczych mają na celu wyjaśnienie tych procesów. Reprezentacje obrazowe i multimodalne mają inne, średnio określone sposoby wskazywania podobieństwa między celem, a źródłem, niż jest to w przypadku języka. O ile dźwięki i obrazy są łatwiej rozpoznawalne ponadnarodowo i globalnie niż (nieznane) języki, metafory obrazkowe i multimodalne pozwalają na większy dostęp międzykulturowy niż werbalny. Źródła obrazowe i multimodalne mają prawdopodobnie silniejszy ładunek emocjonalny niż werbalne. Zidentyfikowane typy metafor mogą występować zarówno w ruchomych, jak i statycznych obrazach. Na zdjęciach jednak, szczególnie statycznych, nie ma takiej liniowości ani gramatycznych „reguł” jednoznacznego określania celu i źródła, dlatego też cel i źródło należy zidentyfikować na innych podstawach. Ruchome obrazy umożliwiają jednak znacznie więcej sposobów konstruowania metafor niż obrazy statyczne. Nawet uwzględniwszy kilka opracowań, trzeba stwierdzić, że metafora multimodalna nie została jeszcze w pełni empirycznie przebadana, stanowi więc przestrzeń do naukowych refleksji i projektów badawczych. Multimodalność jest złożoną koncepcją, której dojrzała teoria musi uwzględniać układy znaków, percepcję sensoryczną i łączące je nośniki materiału. Aby kombinacja dwóch zjawisk mogła być interpretowana jako metafora multimodalna, muszą być spełnione trzy kryteria, z których tylko ostatnie charakteryzuje wyłącznie różnorodność multimodalną. Po pierwsze, biorąc pod uwagę kontekst, w którym występują, domeny docelowa i źródłowa należą do różnych kategorii. Po drugie,

${ }^{18}$ Trevor Wніттоск, Metaphor and film (Cambridge, New York: Cambridge University Press, 1990). 
obie domeny można odpowiednio rozdzielić jako cel i źródło oraz uchwycić $\mathrm{w}$ formacie A jest B, który zmusza lub zaprasza adresata do zmapowania jednej lub więcej cech, konotacji od źródła do celu. Po trzecie, dwa zjawiska (tj. cel i źródło) są przetwarzane w różnych systemach znaków czy trybach sensorycznych.

Podejmowane badania nad metaforą multimodalną powinny być wielokontekstowe i uwzględniać między innymi następujące pytania: w jaki sposób różne wymiary multimodalnej metafory wpływają na jej potencjalne wykorzystanie; które systemy znaków i tryby sensoryczne są wzywane do rozpoznawania domen docelowych i źródłowych; czy metafora występuje w przedstawieniach statycznych czy ruchomych; w jaki sposób jest interpretowane podobieństwo metaforyczne; w jaki sposób producent przekazuje metaforę w sposób jawny lub ukryty ze wskazówkami; jaki wpływ może mieć kontekst kulturowy na odbiór multimodalnych metafor? Wszystkie te wymiary zasługują na dalsze badania teoretyczne i empiryczne - niektóre z nich zostaną wykorzystane do autorskich analiz poszczególnych memów.

\section{CHARAKTERYSTYKA METAFOR WIZUALNYCH - ANALIZY WŁASNE WYBRANYCH PRZYKŁADÓW MEMÓW}

Zgromadzone memowe wizualizacje w większości są egzemplifikacjami metaforycznego myślenia. Wybrane przykłady dziesięciu memów zostały poddane opisowej analizie według czterech porządkujących pytań, właściwych dla analizy metafor: (1) Jakie są dwa terminy metafory — domena źródłowa i docelowa? (2) Który termin jest domeną docelową metafory, który jest domeną źródłową? (3) Jakie cechy domeny źródłowej są mapowane do domeny docelowej? (4) Jakie elementy metafor pierwotnych (primary metaphor) można odszukać w wizualizacjach? Pojęcie metafor pierwotnych jest tu używane w znaczeniu uniwersalnych korelacji między porównywanymi elementami ${ }^{19}$. $\mathrm{W}$ analizach będzie uwzględniona relacja uzupełniająca między elementami werbalnymi i wizualnymi zgodnie $\mathrm{z}$ ustaleniem, że metafora multimodalne to kompozycja znaków słownych i wizualnych. Werbalny kontekst definiuję

\footnotetext{
${ }^{19}$ Zgodnie z propozycją rozwiniętą w pracach: Joseph GRADY, ,A typology of motivation for conceptual metaphor: correlation vs. resemblance", w: Metaphor in Cognitive Linguistics, red. Raymond W. Gibbs i Gerard Steen (John Benjamins Publishing Company, 1999), 79-100; Joseph GRADY, „Primary metaphors as input to conceptual integration”, Journal of Pragmatics, nr 37 (2005): $1595-1614$.
} 
jako wyrażenia językowe, które znajdują się w bliskiej odległości od obrazu oraz są przeznaczone do bezpośredniego odczytania w połączeniu z obrazem.

Dwa pierwsze memy wybrane do analizy (przykłady 1 i 2 ) reprezentują metafory wizualne przedstawiające molekułę koronawirusa.

\section{Kiedy ludzie robią o tobie memy i się z nich śmieją zamiast się ciebie bać}

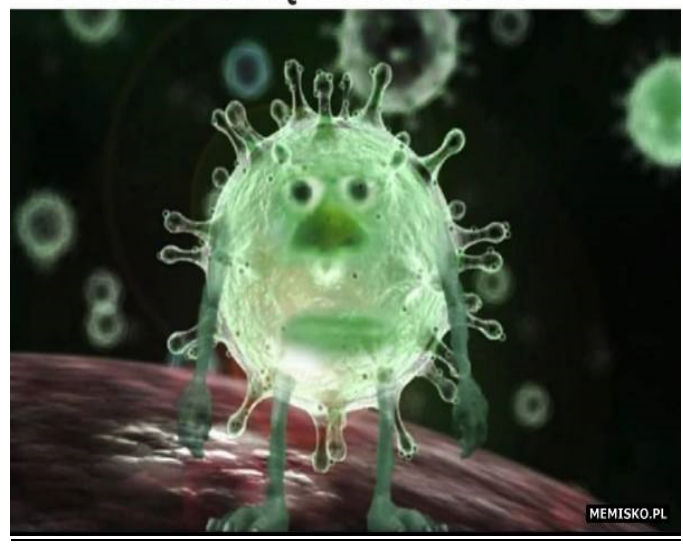

Przykład nr 1

Źródło: GK24.pl, dostęp 25.05.2021, https://gk24.pl/koronawirus-memy-najlepsze-memy-na-tematkoronawirusa-internauci-zartuja-z-koronawirusa-24052021/ga/c15-15419239/zd/47765019

1. Domena źródłowa: Domena jest reprezentowana w trybie wizualnym o metaforycznym znaczeniu. Przedstawienie molekuły odbiega od powszechnie znanego kształtu i koloru. Zazwyczaj koronawirus w materiałach popularyzatorskich i medialnych jest prezentowany w barwie czerwonej - agresywnej i groźnej lub w odcieniu fioletowym, kojarzącym się ze smutkiem i śmiercią. W domenie źródłowej molekuła jest w jasnym, świetlistym kolorze z dominacją kojącego koloru zielonego z wyraźnym zarysowaniem zmysłów wzroku, węchu, ust oraz kończyn w układzie pionowym. Pojawia się zatem mechanizm zastąpienia oczywistego i oczekiwanego elementu (czerwona wielka molekuła wirusa) z nieoczekiwanym burzącym proste, logiczne skojarzenie (zielony stworek).

2. Domena docelowa: Wyobrażenie koronawirusa - domena jest prezentowana $\mathrm{w}$ trybie wizualnym z podpowiedzią werbalną. Warstwa słowna wskazuje, że wirusa należy traktować żartobliwie i nie bać się go (tryb wizualno-werbalny). 
3. Mapowanie cech z domeny źródłowej do domeny docelowej: Sposób przedstawienia molekuły, jej kolor, wielkość, przypisane cechy sugeruje nawiązanie do metafory pierwotnej wielki jest potężny i należy się go bać. $\mathrm{Z}$ drugiej strony zastosowane zabiegi kompozycyjne i plastyczne sugerują odebranie wirusowi siły i mocy. Zarysowanie twarzy i zmysłów i części ludzkiego ciała można zinterpretować jako metaforę opartą na swobodnym plastycznym modelowaniu fizycznego wyglądu.

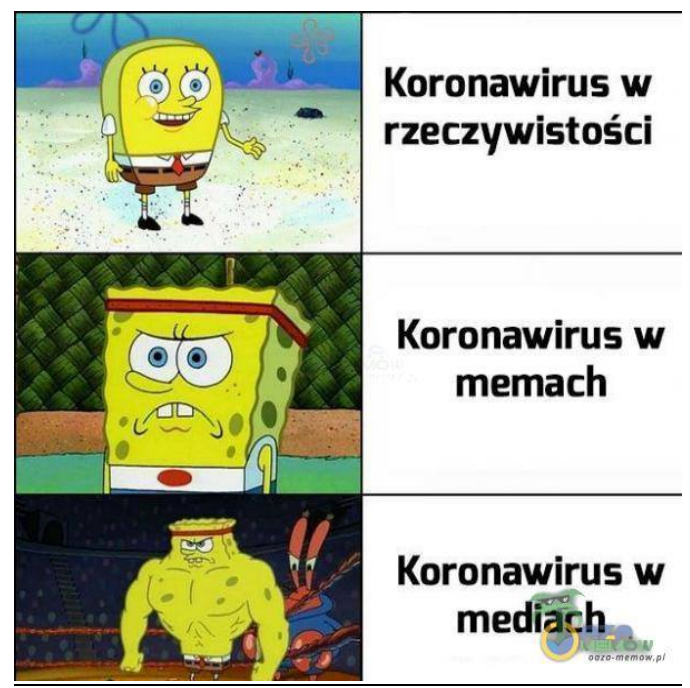

Przykład nr 2

Źródło: GK24.pl, dostęp 25.05.2021, https://gk24.pl/koronawirus-memy-najlepsze-memy-na-tematkoronawirusa-internauci-zartuja-z-koronawirusa-24052021/ga/c15-15419239/zd/47765091

1. Domena źródłowa: Domena jest prezentowana w trybie wizualnym z podpowiedzią werbalną. W wizualizacji wirusa wykorzystano bajkową postać z kreskówki „SpangeBob Kancistoporty”, wymyślonej przez biologa morskiego i animatora bajek Stephena Hillenburga

2. Domena docelowa: Wyobrażenie koronawirusa - domena jest prezentowana $\mathrm{w}$ trybie wizualnym z podpowiedzią werbalną.

3. Mapowanie cech z domeny źródłowej do domeny docelowej (wykorzystanie metafor pierwotnych): Bajki są jedną $\mathrm{z}$ najstarszych form metaforycznych. Wizualizowane cechy postaci SpangeBoba to nieporadność, łatwowierność, naiwność oraz — w zależności od sytuacji — niezadowolenie, zdenerwowanie, złość i agresywna postawa. Mapowane cechy z obiektów źródłowych na koronawirusa są zróżnicowane w zależności 
od publicznej przestrzeni mówienia o nim. W rzeczywistości wirus jest niegroźny i przyjacielski, w memach przybiera postawę lekko groźną, natomiast $\mathrm{w}$ mediach staje się niebezpiecznie groźny i w tym ostatnim przypadku mamy do czynienie z wykorzystaniem metafory rozmiaru wielki jest groźny.

Kolejne przykłady memów (nr 3 i 4) reprezentują metafory wizualne ilustrujące sytuację przymusowej kwarantanny

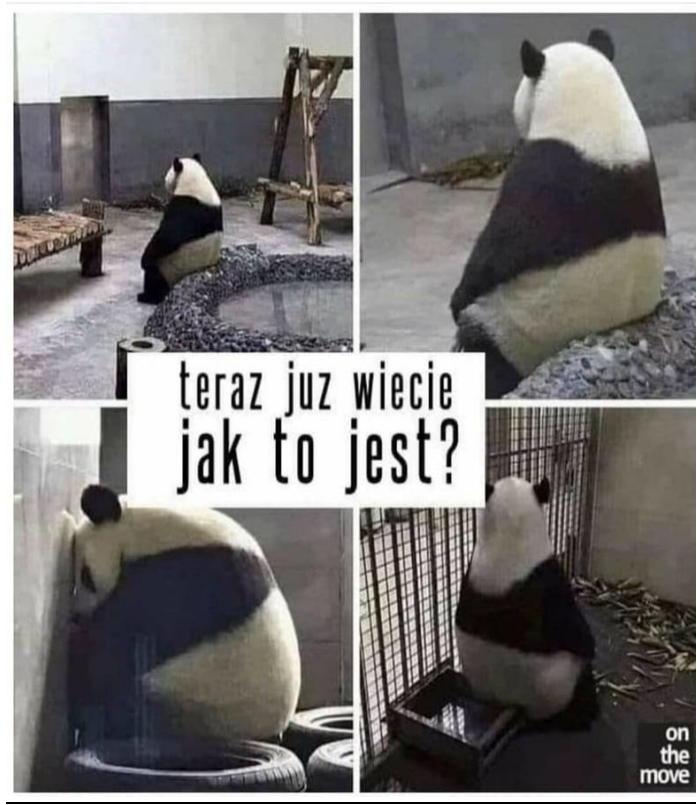

Przykład nr 3

Źródło: Dziennik Polski, dostęp 25.05.2021, https://dziennikpolski24.pl/memy-o-kwarantannie-zobacznajlepsze-memy-o-epidemii-koronawirusa/ga/c15-14929164/zd/43009294

1. Domena źródłowa: Domena jest przedstawiona w trybie wizualnym. Kwarantanna jest zaprezentowana przy zastosowaniu obiektu źródłowego niedźwiadka w niewoli oraz - za pomocą metafory pierwotnej zamknięcia przestrzennego, powodującego izolację nie tylko fizyczną, lecz także psychiczną. Kwarantannie jest przypisana metaforyczna interpretacja izolacji uwięzionego niedźwiadka żyjącego w nienaturalnych „zabetonowanych” warunkach, na które skazał go człowiek.

2. Domena docelowa: Wizualizacja kwarantanny $\mathrm{z}$ dopowiedzeniem werbalnym

3. Mapowanie cech z domeny źródłowej do domeny docelowej (wykorzystanie metafor pierwotnych): Sytuacja niewoli zwierzęcia jest metonimią 
warunków kwarantanny w okresie pandemii. Wielkość obiektu nie przekłada się na poczucie siły - taką interpretację podpowiada metafora pierwotna: wielkość to siła, moc. Rozmiar należy raczej interpretować jako ekspozycję i hiperbolizację problemu.

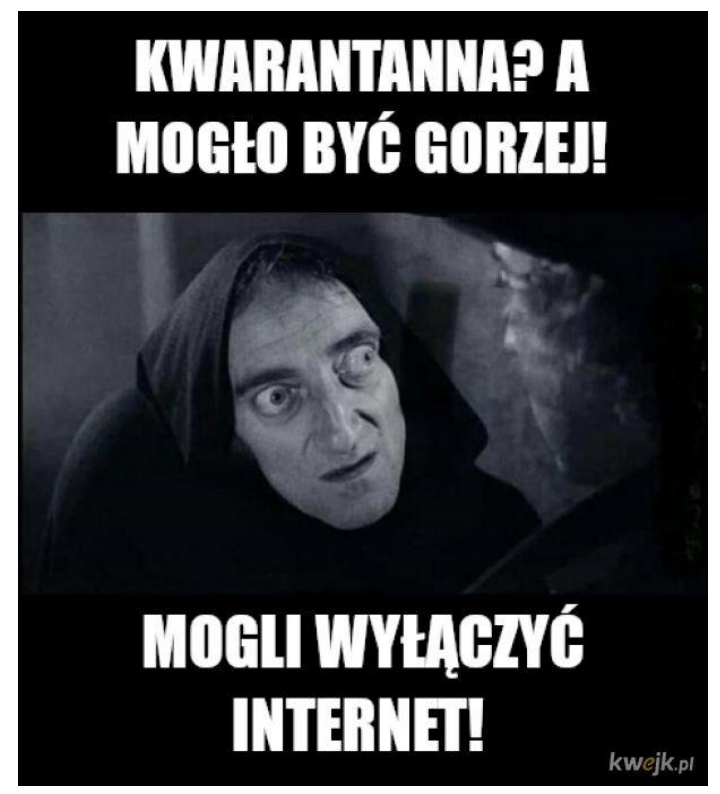

Przykład nr 4

Źródło: Dziennik Polski, dostęp 25.05.2021, https://dziennikpolski24.pl/koronawirus-i-kwarantanna- otonowe-najbardziej-zabawne-memy/ga/c1-14900619/zd/42813751

1. Domena źródłowa: Domena jest zaprezentowana w trybie wizualno-werbalnym z wykorzystaniem kadru z komedii Młody Frankenstein w reżyserii Mela Brooksa z 1974 r., parodiującej horrory i pełnej absurdalnego humoru. Osobowym obiektem źródłowym jest postać Igora — garbatego bohatera, w którego wcielił się Marty Ferdman.

2. Domena docelowa: Wizualizacja kwarantanny z podpowiedzią werbalną (tryb wizualno-werbalny)

3. Mapowanie cech z domeny źródłowej do domeny docelowej (wykorzystanie metafor pierwotnych): Koncepcja przekazu zakłada wykorzystanie pierwotnej metafory złego - zło jest ciemne, która identyfikuje zło jako coś mrocznego, z zachowaniem ciemnych (czarnych) barw. Szpetność wyglądu twarzy i zarys garbu potęguje metaforę. Dopowiedzenie w warstwie słownej kieruje interpretację $\mathrm{w}$ stronę budowania stanu niepewności i zagrożenia, 
a zwłaszcza w kontekście podjęcia decyzji o wyłączeniu Internetu, czyniącej kwarantannę jeszcze bardziej trudną do zniesienia.

Przykłady następne (memy nr 5, 6 i 7) odnoszą się do grupy memów wymyślonych na opisanie aktywności kontrolnych prowadzonych przez służby mundurowe i medyczne.

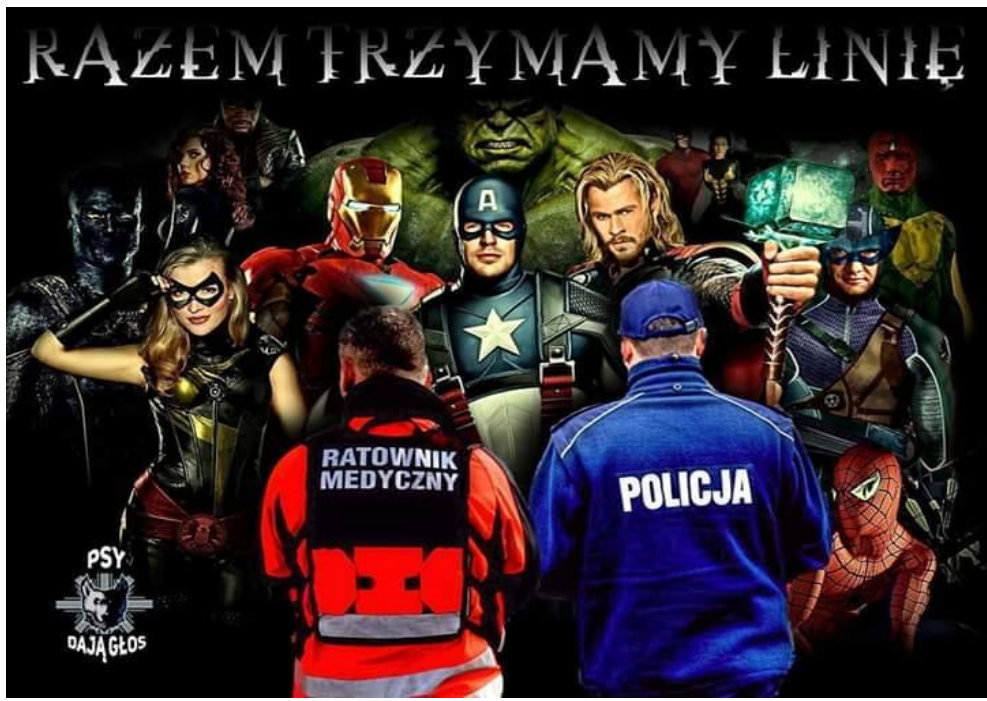

Przykład nr 5

Źródło: Dziennik Polski, dostęp 25.05.2021, https://dziennikpolski24.pl/memy-o-kwarantannie-zobacznajlepsze-memy-o-epidemii-koronawirusa/ga/c15-14929164/zd/43009278

1. Domena źródłowa: Domena jest prezentowana w trybie wizualnym. Osobowe obiekty źródłowe — superbohaterowie hollywoodzkich produkcji są ucieleśnieniem mocy i siły. Metafora działań policji i ratowników medycznych jest oparta na wymiarach przestrzennych i ekspozycji siły wzmocnionej wyrazistymi barwami.

2. Domena docelowa: Wizualizacja skutecznych działań służb mundurowych i medycznych z podpowiedzią werbalną (tryb wizualno-werbalny)

3. Mapowanie cech z domeny źródłowej na domenę docelową (wykorzystanie metafor pierwotnych): wykorzystany katalog postaci superbohaterów jest wkomponowany zwielokrotnianą metaforę pierwotną wieki rozmiar to siła $i$ moc. Nawet wielopostaciowa potęga superbohaterów nie chce zadzierać z policją i służbami medycznymi. Zdyscyplinowani bohaterowie karnie stoją w szeregu. Wykorzystanie fizycznego rozmiaru i ekspozycji za pomocą barwnego kontrastu policjanta i ratownika potwierdza prawo policjantów 
i ratowników medycznych do kontroli innych, a także do wyższego statusu społecznego. Metafora zawiera więc korelację między wysoką pozycją a poczuciem siły i kontroli nad ludźmi, przedmiotami lub sytuacjami.

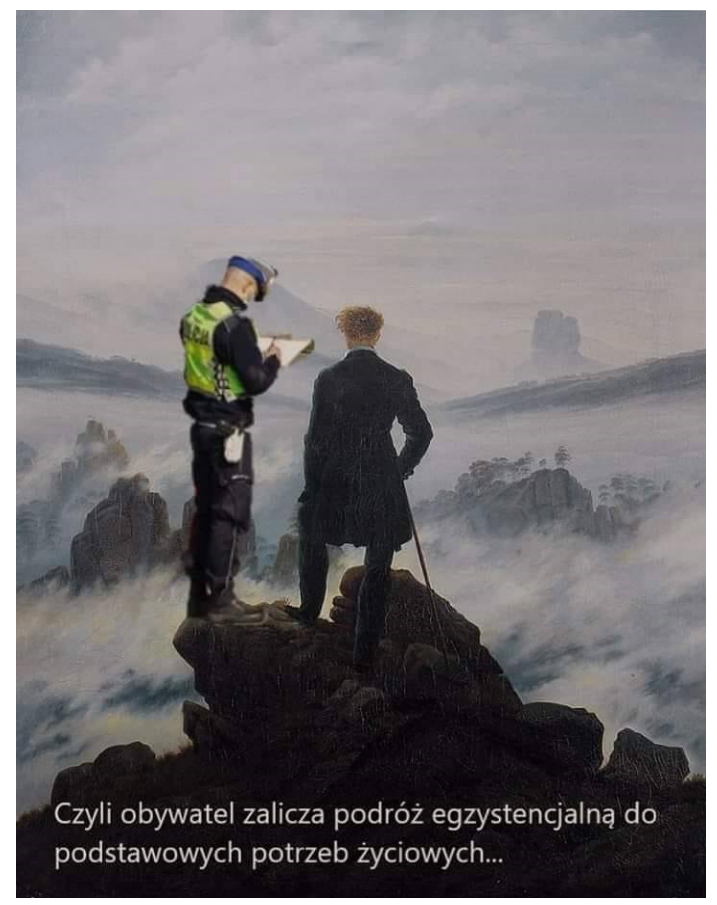

Przykład nr 6

Źródło: Dziennik Polski, dostęp 25.05.2021, https://dziennikpolski24.pl/memy-o-kwarantannie-zobacznajlepsze-memy-o-epidemii-koronawirusa/ga/c15-14929164/zd/43009448

1. Domena źródłowa: Osobowe obiekty źródłowe są reprezentowane przez współczesnego policjanta oraz „niewspółczesnego” poetę z epoki romantyzmu. Otoczenie kontekstowe narzuca skojarzenie z literackim motywem monologu Kordiana na szczycie Mont Blanc z dramatu Kordian Juliusza Słowackiego (tryb wizualny).

2. Domena docelowa: Totalna kontrola służb mundurowych w miejscach odosobnionych, tajemniczych, trudnych do zdobycia i zanegowanie potrzeby samotnych podróży (tryb wizualny z podpowiedzą werbalną)

3. Mapowanie cech z domeny źródłowej do domeny docelowej (wykorzystanie metafor pierwotnych): W wizualizacji odczytujemy dwie powiązane ze sobą metafory pierwotne: wielki jest potężny oraz siła i moc wznosi postać 
ku górze. Pokazanie większego rozmiaru (policjant góruje nad poetą) prowadzi do uznania jego siły i prawa do kontroli. Metafora zawiera korelację między wysoką pozycją a poczuciem siły i kontroli nad przedmiotami, ludźmi lub sytuacjami. Szczegół ręcznego wypisywania mandatu wywołuje jeszcze jedną metaforę wizualną, którą można połączyć z metaforą pierwotną posiadania czegoś w ręku, czyli wzmocnienie znaczenia kontroli nad czymś. Podróż egzystencjalna posłużyła do zbudowania znaczenia metaforycznego stanu psychicznego osób w sytuacji kwarantanny. Aktywności kontrolne dyktowane przestrzeganiem reżimu sanitarnego uniemożliwiają ludziom poszukiwania wewnętrznej doskonałości i duchowego rozwoju. Podróż egzystencjalna jest metonimią pragnienia zmian, targającego niepokoju i tęsknoty.

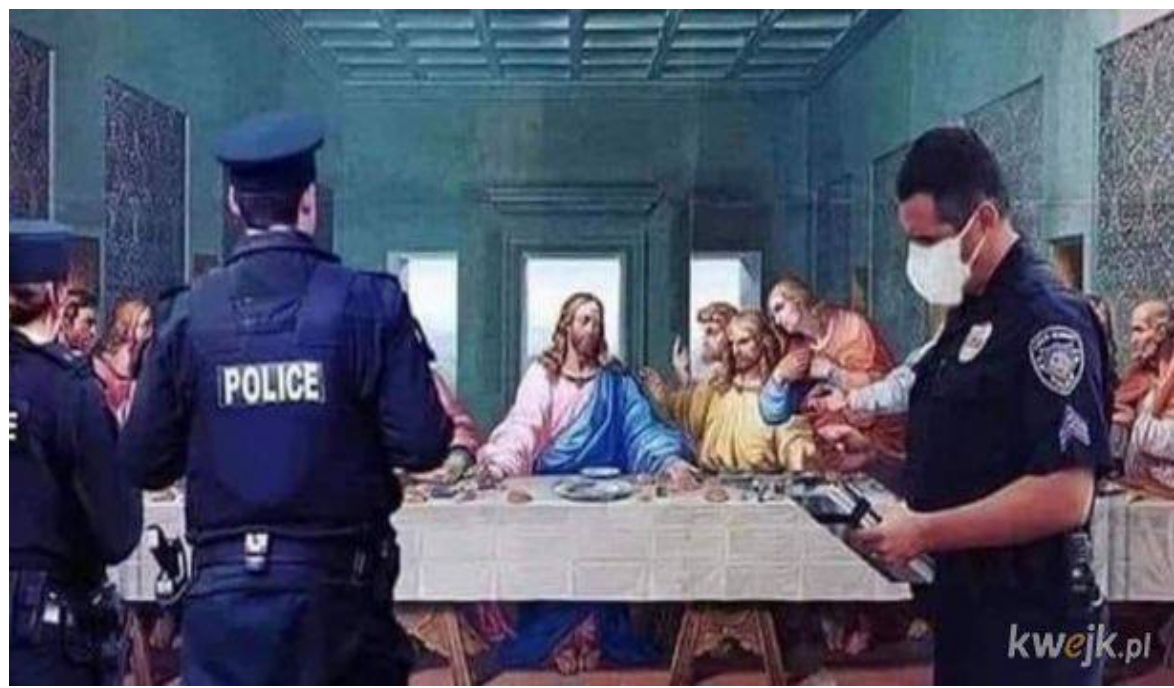

Przykład nr 7

Źródło: Dziennik Polski, dostęp 25.05.2021, https://dziennikpolski24.pl/koronawirus-i-kwarantanna-otonowe-najbardziej-zabawne-memy/ga/c1-14900619/zd/42813713

1. Domena źródłowa: Obiektem źródłowym jest reprodukcja obrazu Giacomo Rafaelli, która jest kopią Ostatniej Wieczerzy Leonarda da Vinci, zlecona malarzowi przez Napoleona na początku XIX wieku. Wizualizacja jest wzbogacona dołączeniem współczesnych policjantów, kontrolujących zgromadzenie religijne (tryb wizualny)

2. Domena docelowa: Praktyki kontrolne wszelkich zgromadzeń (tryb wizualny) 
3. Mapowanie cech z domeny źródłowej do domeny docelowej (wykorzystanie metafor pierwotnych): Wizualizacja pozwala na odszukanie mechanizmu fuzji metaforycznej polegającej na połączeniu oczywistego i oczekiwanego elementu z nieoczekiwanym burzącym proste, logiczne skojarzenie (policjanci na Wieczerzy). Podobnie jak w poprzednim memie pojawia się szczegół ręcznego wypisywania mandatu, który może wywołać dodatkową metaforę pierwotną posiadania czegoś w ręku, czyli pełnej kontroli nad czymś, łącznie z przełamaniem logiki czasowej wydarzeń.

Ostatnią grupę materiałów do analizy reprezentują memy ilustrujące aktywności życia codziennego w okresie pandemii (przykłady nr 8, 9 i 10).

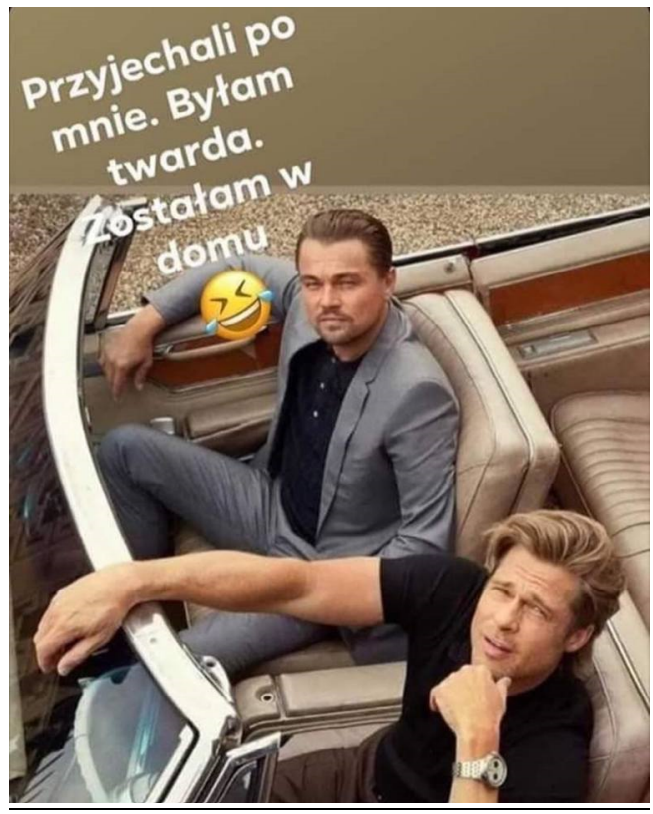

Przykład nr 8

Źródło: Dziennik Polski, dostęp 25.05.2021, https://dziennikpolski24.pl/memy-o-kwarantannie-zobacznajlepsze-memy-o-epidemii-koronawirusa/ga/c15-14929164/zd/43009352

1. Domena źródłowa: Koncepcja domeny oparta jest na wykorzystaniu kadru z amerykańskiego filmu z 2019 r. w reżyserii Quentina Tarantino Pewnego razu... w Hollywood (tryb wizualny)

2. Domena docelowa: Tęsknota za aktywnym atrakcyjnym życiem sprzed kwarantanny (tryb wizualny z podpowiedzią werbalną)

3. Mapowanie cech z domeny źródłowej na domenę docelową (wykorzystanie metafor pierwotnych): Obiekt źródłowy poszerza domenę docelową 
o atrakcyjny zewnętrzny świat zapraszający do luksusowego spędzania czasu i zabawy. W wizualizacji atrakcyjne aktywności są metaforycznie personifikowane przez gwiazdorką parę aktorów: Brada Pitta i Leonardo DiCaprio. Kompozycja tekstu i obrazu pozwala także na odszukanie mechanizmu fuzji metaforycznej, polegającej na połączeniu oczywistego i oczekiwanego elementu (udział w atrakcyjnych aktywnościach) z nieoczekiwanym burzącym proste, logiczne skojarzenie (pozostanie w domu).

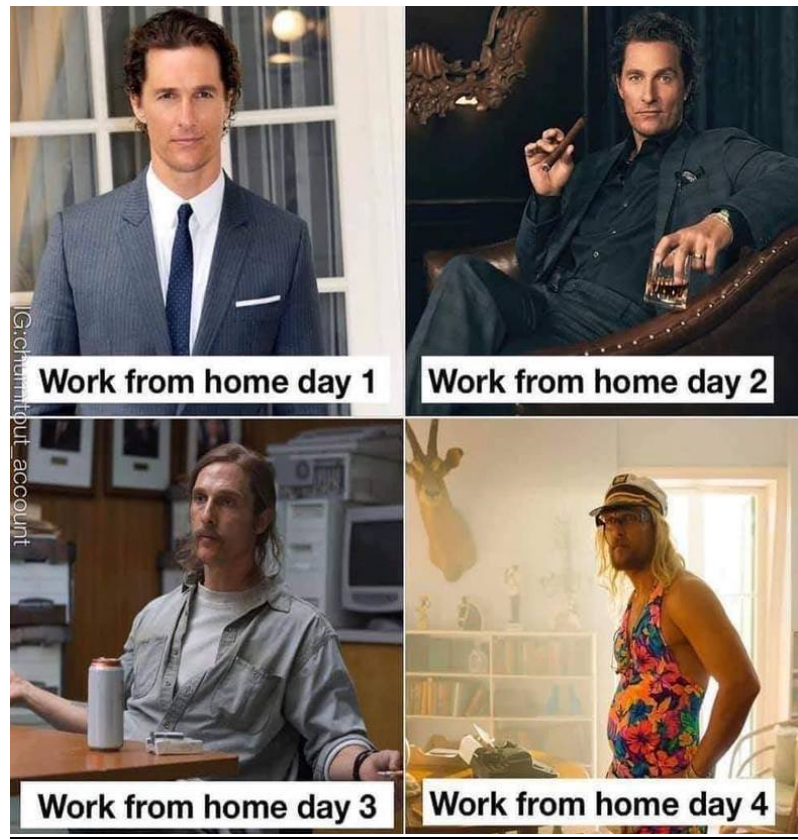

Przykład nr 9

Źródło: Dziennik Polski, dostęp 25.05.2021, https://dziennikpolski24.pl/memy-o-kwarantannie-zobacznajlepsze-memy-o-epidemii-koronawirusa/ga/c15-14929164/zd/43009300

1. Domena źródłowa: Osobowe obiekty źródłowe konceptualizują pracę zdalną w okresie pandemii (tryb wizualny z podpowiedzią werbalną).

2. Domena docelowa: Praca zdalna w okresie pandemii (tryb wizualno-werbalny)

3. Mapowanie cech $\mathrm{z}$ domeny źródłowej do domeny docelowej (wykorzystanie metafor pierwotnych): W kompozycji mema cechy domeny źródłowej poszerzają domenę docelową o nowe konteksty pracy w pandemii w linearnym następstwie czasowym. Odnajdujemy tu zabieg metaforyczny 
personalizacji pracy $\mathrm{w}$ domu. Znaczenie pierwszego dnia pracy zdalnej jest zbudowane na postaci pracownika o nienagannym wyglądzie biznesowym, drugi dzień jest łączony $\mathrm{z}$ wyglądem bardziej swobodnym wraz z atrybutami eleganckich elitarnych używek. Kolejny dzień jest wizualizowany zaniedbanym wylądem i popularnymi odżywkami, by na koniec pracownik zagubił swój tożsamość i pomieszał pełnione przez siebie role.

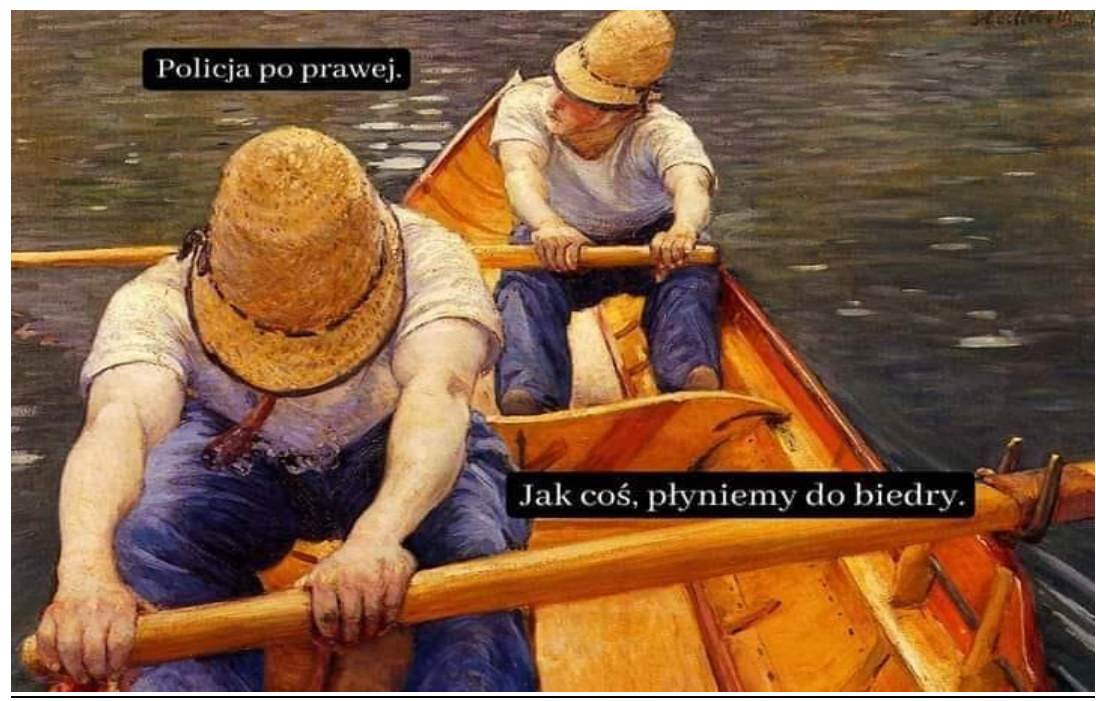

Przykład nr 10

Źródło: Dziennik Polski, dostęp 25.05.2021, https://dziennikpolski24.pl/memy-o-kwarantannie-zobacznajlepsze-memy-o-epidemii-koronawirusa/ga/c15-14929164/zd/43009450

1. Domena źródłowa: Osobowe obiekty źródłowe - wioślarze z poprzedniej epoki konceptualizacją sytuację kontroli policji niedozwolonych aktywności (tryb wizualno-werbalny)

2. Domena docelowa: Wizualizacja praktyk życia codziennego (tryb wizualny z podpowiedzią werbalną)

3. Mapowanie cech z domeny źródłowej na domenę docelową: Analizowany mem jest udaną formą połączenia reprodukcji dzieła sztuki - obrazu Gustave'a Caillebotte'a zatytułowanego Wioślarze - z tekstem, z absurdalnością pandemicznych wydarzeń, charakteryzowanych zapisami rozmowy z użyciem kolokwialnych zwrotów. Metaforyczne znaczenie jest zbudowane na fuzji elementów wizualnych i werbalnych, polegającej na zastąpieniu oczywistego i oczekiwanego elementu (płynący do jakiegoś celu „niewspółczesni” 
wioślarze) z nieoczekiwanym burzącym proste, logiczne skojarzenie (sytuacja kontroli policyjnej i szukanie pretekstu ratującego przed mandatem).

\section{WNIOSKI KOŃCOWE}

Kompozycyjna zawartość memów i opisane przykłady metafor wizualnych, inspirowanych tematami i wydarzeniami z okresu pandemii, pozwalają na wskazanie pewnych prawidłowości o charakterze podsumowującym:

- Konfiguracje domen źródłowych i docelowych są prezentowane w trybach mieszanych - zarówno wizualnych, jak i werbalnych. Domeny źródłowe częściej są monomodalne z zachowaniem trybu wizualnego, natomiast domeny docelowe są multimodalne, w których tryby wizualny i werbalny wzajemnie się uzupełniają oraz wzmacniają znaczeniowo.

- Memy o tematyce pandemii COVID-19 można zaliczyć do konceptów poszerzających zakresy domen źródłowych o teksty kultury w postaci kadrów filmowych czy malarskich.

- W omówionych przykładach znaczeń metaforycznych odszukano elementy uruchamiające metafory pierwotne, najczęściej wyrażające się w następujących korelacjach: (1) między wielkością rozmiaru fizycznego obiektu a jego wartością; między pokazywaniem dużych rozmiarów i siłą; (2) między światłem (bezpieczeństwem, dobrem) i ciemnością (niebezpieczeństwem, złem); (3) między wysoką pozycją a poczuciem siły i kontroli; (4) między zamknięciem przestrzennym i poczuciem izolacji psychicznej; (5) między posiadaniem czegoś w ręku i kontrolą nad tym.

Zaprezentowane ustalenia mogą być przyczynkiem do dalszych badań nad metaforami wizualnymi w memach traktowanych jako współczesny fenomen komunikacyjny i medium ekspresywnej aktywności użytkowników w nowych mediach. $Z$ pewnością znaczenia kodowane w użytych metaforach wizualnych są bogatym poznawczo przejawem kreatywnych i dostosowawczych form twórczości w kulturze sieciowej w czasie globalnej pandemii. 


\section{BIBLIOGRAFIA}

CArroll, Noel. „Visual metaphor”. W: Aspects of Metaphor, red. Jaakko Hintikka, 189-223. Dordrecht: Kluwer, 1994.

CARroll, Noel. „A note on film metaphor”. W: Theorizing the Movie Image, red. Noel Carroll, 212-223. Cambridge: Cambridge University Press, 1996.

Drozdowski, Rafał, i in. Życie codzienne wczasach pandemii. Raport z pierwszego etapu badań. Poznań: Wydział Socjologii UAM, 2020.

EERDEN, Bart. „Anger in Asterix: The metaphorical representation of anger in comics and animate films", w Multimodal metaphor, red. Charles Forceville, Eduardo Urios-Aparisi, 243264. Berlin/New York: Mouton de Gruyter, 2009.

FIUT, Ignacy S. „Filozoficzne konsekwencje memetyki”. Racjonalista, dostęp 25.04.2020, http:// www. racjonalista.pl/ kk.php/t,4712.

ForCEville, Charles. „Metaphors in pictures and multimodal representations”. W: The Cambridge Handbook of Metaphor and Thought, red. Raymond W. Jr. Gibbs, 462-482. Cambridge: Cambridge University Press, 2008.

GradY, Joseph. „A typology of motivation for conceptual metaphor: correlation vs. resemblance". W: Metaphor in Cognitive Linguistics, red. Raymond W. Gibbs, Gerard Steen, 79-100. John Benjamins Publishing Company, 1999.

GRADY, Joseph. „Primary metaphors as input to conceptual integration”. Journal of Pragmatics, nr 37 (2005): 1595-1614.

Hull, David. „Taking Memetics Seriously. Memetics Will Be What We Make It”. W: Darwinizing Culture: The Status of Memetics as a Science, red. Robert Aunger, 43-168. Oxford: University Press, 2000). DOI:10.1093/acprof:oso/9780192632449.001.0001.

Jezierska, Zuzanna. „Poznawcze i emocjonalne charakterystyki memów tworzonych w początkowym etapie pandemii koronawirusa w roku 2020". Fabrica Societatis, nr 3 (2020): 190-200, dostęp 24.05.2021, www.fabricasocietatis.uni.wroc.pl. DOI: 10.34616/129172.

Kennedy, John M. „Metaphor in pictures”. Perception, nr 11(5) (1982): 589-605.

Kennedy, John M., Christopher D. Green i John Vervaeke. „Metaphoric Thought and Devices in Pictures". Metaphor and Symbolic Activity, nr 8(3) (1993): 243-255.

Koller, Veronica. „Brand images: Multimodal metaphor in corporate branding messages”. W: Multimodal metaphor, red. Charles Forceville i Eduardo Urios-Aparisi, 45-71. Berlin/ New York: Mouton de Gruyter, 2009.

Konstantineas, Charalambos, i Georg Vlachos. „Internet Memes: Humour in Late Modernity and Encroachment upon the Mainstream", INTER-DISCIPLINARY.NET. A Global Network for Dynamic Research and Publishing, dostęp 20.04.2021, http://www.inter-disciplinary.net/ critical-issues/wpcontent/uploads/2012/06/vlachosvispaper.pdf.

Krąiec, Mieczysław A. „Analogia”. W: Wprowadzenie do filozofii. Lublin: Redakcja Wydawnictw KUL, 1992.

LiBurA, Agnieszka. Wyobraźnia w języku. Leksykalne korelaty schematów wyobrażeniowych, Wrocław: Centrum — Peryferie — Siły, 2000.

NowAK, Jakub. „Memy internetowe. teksty (cyfrowej) kultury językiem krytyki społecznej”. W: Współczesne media. Język mediów, red. Iwona Hofman i Danuta Kępa-Figura, 227-238. Lublin: Wydawnictwo Uniwersytetu Marii Curie-Skłodowskiej, 2013. 
Phillips, Barbara J. „Understanding visual metaphor in advertising”. W: Presuasive Imagery: A Consumer Response Pespective, red. Linda M. Scott, Rajeev Batra, 297-310 Mahwah, $\mathrm{NJ} /$ London: Lawrence Erlbaum, 2003.

Shifman, Limor. „Memes in a Digital World. Reconciling with a Conceptual Troublemaker”, Journal of Computer-Mediated Communication, nr 18 (2013): 362-377.

Shinohara, Kazuko, i Yoshihiro Matsunaka. „Pictorial metaphors of emotion in Japanese comics", w Multimodal metaphor, red. Charles Forceville, Eduardo Urios-Aparisi, 265-296, Berlin/ New York: Mouton de Gruyter, 2009.

Walkiewicz, Adam. „Czym są memy internetowe? Rozważania z perspektywy memetycznej”, Teksty z Ulicy. Zeszyt Memetyczny nr 12(2012): 50-69.

Wніттоск, Trevor. Metaphor and film. Cambridge, New York: Cambridge University Press, 1990.

Wiggin, Amy A., i Christine M. Miller. „Uncle Sam Wants You! Exploring Verbal-Visual Juxtapositions in Television Advertising”, w Presuasive Imagery. A Consumer Response Perspective, red. Linda M. Scott and Rajeev Batra, 267-295. Mahwah, NJ/London: Lawrence Erlbaum, 2003.

Velasco, Marisol, i Pedro Fuertes. „Towards a critical cognitive-pragmatic approach to gender metaphors in Advertising English”, Journal of Pragmatics, nr 38(11) (2006): 1982-2002.

Velasco, Marisol, i Pedro Fuertes. „Olfactory and olfactory-mixed metaphors in print ads of perfumes", Annual Review of Cognitive Linguistics, nr 4 (2006): 217-252

Ventola, Eija, Charles Cassiliy, i Martin Kaltenbacher. Perspectives on Multimodality. Amsterdam: Benjamins, 2004.

\section{METAFORY WIZUALNE PANDEMII COVID-19 \\ W MEMACH INTERNETOWYCH}

\section{Streszczenie}

Zasadniczym celem artykułu jest charakterystyka metafor wizualnych o pandemii COVID-19 w memach internetowych. Struktura artykułu jest następująca: w pierwszej części omawiam zagadnienia teoretyczne dotyczące memów i metafor wizualnych, które są istotne dla dalszych analiz własnych; druga część jest poświęcona metodologii i analizom szczegółowym wybranych przykładów memowych metafor wizualnych pandemii. Poruszone zostały cztery zagadnienia: jakie są dwa terminy metafory — domena źródłowa i docelowa; który termin jest domeną docelową metafory, a który domeną źródłową; jakie cechy domeny źródłowej są mapowane do domeny docelowej; jakie elementy metafor pierwotnych (primary metaphor) można odszukać w wizualizacjach. Ostatnia część zawiera kilka uwag końcowych o charakterze podsumowującym.

Słowa kluczowe: memy; pandemia COVID-19; metafory wizualne; metafory monomodalne; metafory multimodalne.

\section{VISUAL METAPHORS OF THE COVID-19 PANDEMIC IN INTERNET MEMES}

Su m m a ry

The main goal of the article is to description of visual metaphors about the pandemic COVID-19 in Internet memes. The structure of the paper is a follows: in the first section, I consider the two basic theoretic components of this paper, i.e memes and visual metaphors which are relevant for 
further own analysis, then in the second section I present the methodology and detailed analyzes of ten selected examples of visual metaphors of a pandemic. Four issues are addressed: What are the two terms of the metaphor - source and target domain; Which term is the target domain of the metaphor, which is the source domain; What characters of the source domain are mapped to the target domain; What elements of primary mataphors can be found in the visualizations. The last part contains some concluding remarks.

Keywords: memes; COVID-19 pandemic; visual metaphors; monomodal metaphors; multimodal metaphors. 